\title{
Proteomic Changes in Chick Brain Proteome Post Treatment with Lathyrus Sativus Neurotoxin, $\beta$-N-Oxalyl-L- $\alpha, \beta$-Diaminopropionic Acid (L-ODAP): A Better Insight to Transient Neurolathyrism
}

\author{
Anil Kumar D', Sumathi Natarajan', Nabil A M Bin Omar', Preeti Singh², Rohan Bhimani', \\ and Surya Satyanarayana Singh ${ }^{1}$ \\ ${ }^{1}$ Department of Biochemistry, University College of Science, Osmania University, Hyderabad, Telangana, India \\ ${ }^{2}$ Bharati Vidyapeeth Medical College, Pune, Maharashtra, India \\ ${ }^{3}$ Hinduja Healthcare, Khar West, Mumbai, Maharashtra, India
}

\begin{abstract}
Neurolathyrism is a neurodegenerative disorder characterized by spastic paraplegia resulting from the excessive consumption of Lathyrus sativus (Grass pea). $\beta$-N-Oxalyl-L- $\alpha, \beta$-diaminopropionic acid (L-ODAP) is the primary neurotoxic component in this pea. The present study attempted to evaluate the proteome-wide alterations in chick brain $2 \mathrm{hr}$ and $4 \mathrm{hr}$ post L-ODAP treatment. Proteomic analysis of chick brain homogenates revealed several proteins involved in cytoskeletal structure, signaling, cellular metabolism, free radical scavenging, oxidative stress and neurodegenerative disorders were initially up-regulated at $2 \mathrm{hr}$ and later recovered to normal levels by $4 \mathrm{hr}$. Since L-ODAP mediated neurotoxicity is mainly by excitotoxicity and oxidative stress related dysfunctions, this study further evaluated the role of L-ODAP in apoptosis in vitro using human neuroblastoma cell line, IMR-32. The in vitro studies carried out at $200 \mu \mathrm{M}$ L-ODAP for $4 \mathrm{hr}$ indicate minimal intracellular ROS generation and alteration of mitochondrial membrane potential though not leading to apoptotic cell death. L-ODAP at low concentrations can be explored as a stimulator of various reactive oxygen species (ROS) mediated cell signaling pathways not detrimental to cells. Insights from our study may provide a platform to explore the beneficial side of LODAP at lower concentrations. This study is of significance especially in view of the Government of India lifting the ban on cultivation of low toxin Lathyrus varieties and consumption of this lentil.
\end{abstract}

Key words: L-ODAP, Neurolathyrism, Chick brain proteome, Mitochondria membrane potential, Caspase, Apoptosis

\section{INTRODUCTION}

Grass pea (Lathyrus sativus L., Leguminosae) is a drought crop that is cultivated in parts of Asia, Middle East, and Africa as food for humans and fodder for animals, owing to its nutritive value and economic significance (1-4). Since the prolonged and exclusive consumption of grass pea triggers a characteristic form of spastic paraparesis known as neurolathyrism in animals and humans (5-7), its cultivation was banned in certain countries $(2,6,8)$. The agent responsible for this cortical motor neuron disease appears to be $\beta$ - $N$-oxalyl-L- $\alpha, \beta$-diaminopropionic acid (L-ODAP), also known as $\beta-N$-oxalyl-amino-Lalanine present in the seed as the free amino acid (9-14).
Correspondence to: Anil Kumar D, Department of Biochemistry, University college of science, Osmania university, Hyderabad, Telangana 500007, India

E-mail: 74anilkumar@gmail.com

Abbreviations: ODAP, N-oxalyl-L- $\alpha, \beta$-diaminopropionic acid; PEBP1, phosphatidylethanolamine binding protein 1; HIF, hypoxia inducible factor; ROS, reactive oxygen species; IEF, isoelectric focusing; ACN, acetonitrile; DCFH-DA, 2,7'-dichlorodihydrofluorescein diacetate; DCF, 2',7'-dichlorofluorescein.

\begin{abstract}
This is an Open-Access article distributed under the terms of the Creative Commons Attribution Non-Commercial License (http:// creativecommons.org/licenses/by-nc/3.0) which permits unrestricted non-commercial use, distribution, and reproduction in any medium, provided the original work is properly cited.
\end{abstract}


L. sativus, a drought-resistant crop, once widely grown in Africa and Asia, was banned due to the outbreak of lathyrism. Ever since the discovery of L-ODAP as the neurotoxin responsible for lathyrism, extensive studies have been conducted focusing on its mechanism of action, reasons for its neurotoxicity, and neutralization of its toxic effects by antioxidants (15). Previous studies report excitotoxicity and oxidative stress-related dysfunctions as partial causes of ODAP-mediated neurotoxicity (16). Animal studies have shown the $\alpha$-isomer of ODAP (D-ODAP) to be less neurotoxic than the $\beta$-isomer (L-ODAP) (17) or nonneurotoxic when introduced into the cerebrospinal fluid (18). D-ODAP lacks neurotoxic properties when tested in tissue culture (14). The prolonged consumption of LODAP and transport across the blood brain barrier indicates that it potentially affects the central nervous system and over time, results in motor neuron disease (19).

Molecular mechanisms proposed to explain the neurotoxicity of L-ODAP generally emphasize that its pharmacological and structural analogs act on the excitatory amino acid glutamate (20-22). L-ODAP exerts its effects by causing an imbalance in calcium homeostasis (23) and free radical-mediated mitochondrial dysfunction (24). LODAP plays a prominent role in signaling, wherein it is known to activate calcium-dependent protein kinase C (25), mimic conditions of hypoxia leading to the down-regulation of phosphatidylethanolamine binding protein 1 (PEBP1), and activate hypoxia inducible factor (HIF)-1 $\alpha$ (26).

Incidences of neurolathyrism have declined remarkably in the past few decades due to changes in economic conditions and as part of balanced diet. Today, research on LODAP is mainly focused on the detoxification pathways and positive aspects of homoarginine in grass pea (27); recent studies have focused on angiogenesis (28), vasodilation, and adaptations to hypoxia $(25,29,30)$. Patents filed in recent years highlight the therapeutic value of this amino acid in hemorrhage, chronic hypoxia-induced neurodegeneration, thrombocytopenia, and oral cavity problems. With the USA and China acquiring patents on ODAP based on its therapeutic applications (29), development of grass pea varieties with low ODAP content (31), and the recent lifting of the ban by the Indian government on the cultivation of grass pea (32), there is a new revolution in the way grass pea and lathyrism are perceived. Nutrientrich food crops with minimal water demands such as grass pea can play a critical role in alleviating global malnutrition.

Although current research is focused on tapping the therapeutic potential of L-ODAP, there has not been any study evaluating the effects of this molecule on brain protein profiles. The present study aims to the compare the brain proteome in four-day-old young white leghorn male chicks following the administration of ODAP with focus on transient lathyrism and/or recovery. Proteins involved in cytoskeletal structure formation, signaling, cellular metabolism, oxidative stress response, and those known to play roles in neurodegenerative disorders such as Alzheimer's and Parkinson's diseases were initially up-regulated at $2 \mathrm{hr}$ and later returned to normal levels by $4 \mathrm{hr}$ corroborating with features of transient lathyrism observed in chicks. Further in vitro assays carried out with $200 \mu \mathrm{M} \mathrm{L}-$ ODAP on the human neuroblastoma cell line IMR-32 indicated a 1.2-fold increase in intracellular reactive oxygen species (ROS) production and a 1.8-fold increase in cells with a depolarized mitochondrial membrane; however, it did not affect apoptosis or the levels of active caspases. These findings open up avenues for evaluating L-ODAP as a stimulator of various ROS-mediated signaling pathways without being toxic to cells, which can be further explored.

\section{MATERIALS AND METHODS}

Materials. D-ODAP and L-ODAP were a generous gift from Lathyrus technologies (Hyderabad, India).

Immobilized $\mathrm{pH}$-gradient strips ( $\mathrm{pH}$ range $3 \sim 10$ ), carrier ampholyte (Biolyte ${ }^{\mathrm{TM}} 3 \sim 10$ ) were purchased from Bio-Rad Laboratories (CA, USA), a broad-range molecular marker was purchased from Genei (Bangalore, India), and all reagents required for $2 \mathrm{D}$ electrophoresis were procured from Sigma Aldrich (MO, USA).

Experimental animals. Four-day-old white leghorn male chicks (Gallus gallus domesticus) were purchased from Venkateswara Hatcheries Pvt. Ltd. (Hyderabad, India). The experiments were conducted following approval from the University Ethical Committee (383/01/a/CPCSEA) and comply with the laws of India. As our study required isolation of the brain for profiling protein expression, the chicks were killed by cervical dislocation and all efforts were made to minimize suffering.

Cell culture. Human neuroblastoma cell line IMR-32 was procured from National Centre for Cell Science, Pune, India. The cells were cultured in minimum essential medium (Sigma Aldrich) supplemented with 10\% FBS (PAN Biotech, Aidenbach, Germany), $2 \mathrm{mM}$ L-glutamine, penicillin $(100 \mathrm{U} / \mathrm{mL})$, streptomycin $(0.1 \mathrm{mg} / \mathrm{mL})$, amphotericin B $(2.5 \mu \mathrm{g} / \mathrm{mL})$, and nystatin $(100 \mathrm{U} / \mathrm{mL})$. Cells were grown and maintained in surface-treated cell culture ware at $37^{\circ} \mathrm{C}$ in a humidified atmosphere with $5 \% \mathrm{CO}_{2}-95 \%$ air. Cells were made quiescent by overnight incubation in serum-free medium prior to stimulation with ODAP.

Treatment of four-day-old white leghorn male chicks with D- and L-ODAP. D-/L-ODAP was injected intraperitoneally $(0.5 \mathrm{mg} / \mathrm{g}$ body weight) to white leghorn male chicks ( $n=6$ chicks per group). The chicks were sacrificed by cervical dislocation at 2 and $4 \mathrm{hr}$, and the brains 
were dissected. Control group consisted of untreated chicks.

2D electrophoresis. Control and ODAP-treated brains were washed in PBS followed by homogenization in a lysis buffer [100 mM Tris (pH 7.4), $200 \mathrm{mM} \mathrm{NaCl}, 0.1 \%$ (v/v) Triton X-100, $2.5 \mathrm{mM}$ EDTA, $2 \mathrm{mM}$ ethylene glycol tetraacetic acid, $50 \mathrm{mM} \mathrm{NaF}, 1 \mathrm{mM} \mathrm{Na} \mathrm{VO}_{4}, 1 \mathrm{mM}$ DTT, and $1.4 \mathrm{mM} \mathrm{PMSF].} \mathrm{The} \mathrm{brains} \mathrm{were} \mathrm{initially}$ homogenized by using a Dounce homogenizer and the homogenates were later pushed 2 3 times through a 26gauge syringe needle to ensure uniform lysis. Following this, the homogenates were centrifuged at $20,000 \times g$ at $4^{\circ} \mathrm{C}$ for $30 \mathrm{~min}$. The supernatants were collected and acetone-precipitated, followed by resuspension in a $2 \mathrm{D}$ rehydration sample buffer [8 M urea, 2\% (w/v) CHAPS, $50 \mathrm{mM}$ DTT, $0.2 \%$ (Biolyte $3 / 10$ ampholytes), and $1 \mu \mathrm{g} /$ $\mathrm{mL}$ protease inhibitors] and stored at $-80^{\circ} \mathrm{C}$ until further use.

A total of $400 \mu \mathrm{g}$ of protein was loaded onto $17-\mathrm{cm}$ immobilized $\mathrm{pH}$-gradient strips of $\mathrm{pI} 3 \sim 10$ (Bio-Rad) and allowed to rehydrate overnight at $17^{\circ} \mathrm{C}$. Isoelectric focusing (IEF) was carried out at $20^{\circ} \mathrm{C}$ with Bio-Rad PROTEAN IEF cell for $60,000 \mathrm{Vh}$ according to the manufacturer's protocol. Following IEF, the strips were equilibrated in an equilibration buffer $[0.375 \mathrm{M}$ Tris- $\mathrm{HCl}(\mathrm{pH} 8.8), 6 \mathrm{M}$ urea, 20\% (v/v) glycerol, 2\% (w/v) SDS, and 2\% (w/v) DTT] for $10 \mathrm{~min}$ and then with the same buffer without DTT but with $2.5 \%(\mathrm{w} / \mathrm{v})$ iodoacetamide for $10 \mathrm{~min}$. 2D electrophoresis was performed using $9 \sim 16 \%$ gradient gel at $16 \sim 24 \mathrm{~mA} / \mathrm{gel}$. Gels were fixed in a solution composed of $50 \%(\mathrm{v} / \mathrm{v})$ methanol and $12 \%(\mathrm{v} / \mathrm{v})$ acetic acid for $1 \mathrm{hr}$ followed by colloidal coomassie brilliant blue G250 staining for $48 \mathrm{hr}$. The gels were destained in $18 \mathrm{Mohm}$ water for $24 \mathrm{hr}$.

Gel imaging and analysis. The $2 \mathrm{D}$ gels were scanned and imaged using GE scanner III. To study and compare the protein expression profile between control and ODAP treatment groups, the gel images were analyzed with Image Master 2D platinum software (version 7.0, Little Chalfont, UK). The general method of software analysis for a pair of gels involved spot detection, background subtraction, aligning, matching, and quantification along with detailed manual checking. The spots were detected based on three parameters: (A) Smoothness $=3$, (B) Saliency $=$ 700 , and $(C)$ Minimum area $=5$. After matching and wrapping the gels, the protein spots among the treated and control pairs were compared and evaluated based on their spot area, intensity, volume, and \% spot volume. The \% spot volumes were normalized using the "ratio method of normalization" option provided in the software. The foldchanges were calculated using averaged means of normalized $\%$ spot volumes of three $2 \mathrm{D}$ gels loaded with biological replicates $(\mathrm{n}=3)$.
In-gel digestion of spots with trypsin. Proteins differentially regulated were excised, washed, and in-gel digested with trypsin. Briefly, protein spots of interest were picked from gels and transferred into microcentrifuge tubes. The spots were washed twice with 18.2 Mohm water for approximately $15 \mathrm{~min}$. Then, $100 \mu \mathrm{L}$ of a $50 \%$ (v/v) acetonitrile $(\mathrm{ACN}) / 50 \% \quad 25 \mathrm{mM} \quad \mathrm{NH}_{4} \mathrm{HCO}_{3}$ was added to each tube and the gel pieces were destained for $15 \mathrm{~min}$. The gel pieces were dehydrated with $100 \mu \mathrm{L}$ of ACN for $5 \mathrm{~min}$. This was followed by a second wash with $25 \mathrm{mM} \mathrm{NH} \mathrm{NHCO}_{3}$ and $50 \%$ ACN with a time gap of 5 min between each wash. After the solution was decanted again, the pieces were dried for 20 30 min in a SpeedVac, and rehydrated with a minimal volume of trypsin solution $\left(10 \mu \mathrm{g} / \mathrm{mL}\right.$ of trypsin in $25 \mathrm{mM} \mathrm{NH}_{4} \mathrm{HCO}_{3} \mathrm{pH}$ $8.0)$ in an incubator at $37^{\circ} \mathrm{C}$ for $16 \mathrm{hr}$. At the end of the digestion, 25 50 $\mu \mathrm{L} \mathrm{75 \%} \mathrm{(v/v)} \mathrm{ACN/25 \%} \mathrm{(v/v)} \mathrm{0.1 \%} \mathrm{TFA}$ was added to each gel piece and incubated for $30 \mathrm{~min}$ in a sonicator bath, following which the peptide extract was transferred to a fresh tube. A second extraction was performed by adding $25 \mu \mathrm{L}$ of $50 \%$ (v/v) $\mathrm{ACN} / 50 \%$ (v/v) $0.1 \%$ TFA to each gel piece, and incubated for $30 \mathrm{~min}$ in a sonicator bath. This solution was combined with the previous extract and was concentrated in a Speed-Vac down to $5 \sim 10 \mu \mathrm{L}$.

Mass spectrometry. Peptide mass fingerprinting of peptide extracts was carried out by MALDI-TOF/TOF (Autoflex III Smartbeam, Bruker Ltd., Billerica, MA, USA). Aliquots $(1 \mu \mathrm{L})$ of peptide samples mixed with $1 \mu \mathrm{L}$ of matrix solution $[1 \%(\mathrm{w} / \mathrm{v})$ of $\mathrm{CHCA}$ in $70 \%(\mathrm{v} / \mathrm{v}) \mathrm{ACN}$ and $30 \%$ of $0.1 \%(\mathrm{v} / \mathrm{v})$ TFA] were applied to the target ground steel plate and allowed to dry. Before analysis, the instrument was calibrated with mass standards: bradyki$\operatorname{nin}(\mathrm{m} / \mathrm{z}$ 757.39), angiotensin II (m/z 1046.54), angiotensin I (m/z 1296.68), substance P (m/z 1347.33), bombysin (m/z 1619.82), ACTH fragment $1 \sim 17$ (m/z 2093.08), fragment 18 39 (m/z 2465.39), and somatostatin (m/z 3147.47). Spectra were obtained in the reflectron mode (mass range of 500 3000 Da, $20 \mathrm{keV}$ accelerating voltage, and averaging 500 laser shots per spectrum) using a MALDI-TOF/ TOF spectrometer with Flex Control software (version 3.3, Bruker Ltd.). For peptide mass fingerprinting, the generated peptide mass lists were exported to Biotools software (version 3.2, Bruker Daltonics) using Flex Analysis software (version 3.3, Bruker Daltonics) with the following parameters: signal-to-noise threshold, 6; mass exclusion tolerance, $0.75 \mathrm{~m} / \mathrm{z}$; maximal number of peaks, 100; quality factor threshold, 50; and monoisotopic peaks, Adduct H. Matrix and/or auto-proteolytic trypsin peaks or known contaminant ions were excluded. Bioinformatics data mining was performed using an in-house licensed version of the MASCOT database search engine (Matrix science, Boston, MA, USA; http://www.matrixscience.com/). 
The resulting peptide mass lists were queried in the NCBInr database (2013.03.30, 24,066,722 sequences). The following criteria were used for search parameters: taxonomy, chordata (vertebrates and relatives, 1,979,745 sequences); significant protein MOWSE score at $p<0.05,1$ missed cleavage site allowed; $1+$ peptide charges allowed; trypsin as enzyme; $80 \sim 100$ ppm as precursor tolerance; carbamidomethylation of cysteine as global modification, and oxidation of methionine as variable modification. Proteins that returned MOWSE scores over a threshold of 50 were considered significant. Further analysis and functionbased classification of the identified proteins were performed using the Protein Center software (version 3.10) by Thermo Fisher Scientific (Waltham, MA, USA).

Mitochondrial membrane potential assay. IMR-32 cells at a density of $4 \times 10^{5}$ cells $/ \mathrm{mL}$ in serum-free medium were treated with $200 \mu \mathrm{M}$ D- and L-ODAP for $4 \mathrm{hr}$. Following treatment, the cells were assayed for loss of mitochondrial inner transmembrane potential using the flow cytometry-based MitoPotential Kit (Millipore, Guava Easycyte, Burlington, MA, USA) according to the manufacturer's protocol. The cells were washed in PBS, stained with JC-1 for $30 \mathrm{~min}$, and acquired by Guava Easycyte 8HT flow cytometer (Millipore) using the in-built MitoPotential software (Millipore). The samples were analyzed for mitochondrial membrane polarization based on the fluorescence of JC-1 using the FlowJo software (version 7.6; Treestar Inc.) (Ashland, OR, USA).

Intracellular ROS assay. To quantify intracellular ROS production, 2',7'-dichlorodihydrofluorescein diacetate (DCFH-DA) was used. It is a cell-permeable non-fluorescent compound, which in the presence of ROS, is oxidized to the fluorescent 2',7'-dichlorofluorescein (DCF) $(33,34)$. Briefly, IMR-32 cells were seeded in six-well plates at a density of $1 \times 10^{5}$ cells/well in minimum essential medium with $10 \%$ FBS and cultured for $24 \mathrm{hr}$. Cells were serum-starved overnight and treated with $200 \mu \mathrm{M}$ Dand L-ODAP for $4 \mathrm{hr}$. Cells challenged with $100 \mu \mathrm{M} \mathrm{H}_{2} \mathrm{O}_{2}$ for $1 \mathrm{hr}$ were used as positive control. Following treatment, cells were rinsed with PBS and incubated with $10 \mu \mathrm{M}$ DCFH-DA for $30 \mathrm{~min}$ at $37^{\circ} \mathrm{C}$. After washing twice with PBS, cells were trypsinized and suspended in serum-free medium. The cell fluorescence was detected using a flow cytometer (Millipore) with excitation and emission at 488 and $530 \mathrm{~nm}$, respectively. Further analysis of the acquired data was carried out using the FlowJo software (Treestar Inc.).

Annexin V-FITC staining. Exposed phosphatidylserine was detected by reaction with FITC-coupled annexin V. Briefly, cells treated with $200 \mu \mathrm{M}$ D- and L-ODAP for $4 \mathrm{hr}$ in serum-free medium were washed twice with PBS.
The cells at a density of $1 \times 10^{6}$ were resuspended in $70 \mu \mathrm{L}$ binding buffer, $5 \mu \mathrm{L}$ annexin V-FITC (Immunotools) was added, and the cells were incubated for $20 \mathrm{~min}$ at room temperature in the dark. Then, $130 \mu \mathrm{L}$ PBS was added to the cell suspension prior to acquisition on Guava Easycyte 8HT flow cytometer (Millipore) with a 488-nm excitation laser and 525/30-nm bandpass filter for fluorescence acquisition from annexin V-FITC. Further analysis of the acquired data was carried out using the FlowJo software (Treestar Inc.).

Multi-caspase assay. IMR-32 cells at a density of $1 \times 10^{6}$ cells $/ \mathrm{mL}$ in serum-free medium were treated with $200 \mu \mathrm{M}$ D- and L-ODAP for $4 \mathrm{hr}$, and multi-caspase levels in cells were assayed using the Multi-Caspase FAM kit (Millipore, Guava Easycyte) according to manufacturer's protocol. Cells were stained with a cell-permeable active caspase inhibitor linked to FAM for $30 \mathrm{~min}$, and green fluorescence was determined using the Express Pro software of Guava Easycyte 8HT flow cytometer (Millipore). Further analysis was carried out with the FlowJo software (Treestar Inc.).

Statistical analysis. All experiments were carried out in triplicate, and values are expressed as mean \pm standard error of mean. Significant differences in the protein expression between the two groups were determined by the unpaired two-tailed Student's $t$-test using GraphPad software where a $p$-value less than 0.05 was considered statistically significant; for multiple group comparison, oneway analysis of variance was applied, followed by Bonferroni post-hoc two-tailed $t$-test. * indicates $p<0.05$ and ** indicates $p<0.005$, which were considered statistically significant.

\section{RESULTS}

Proteome analysis of chick brain homogenates following L-ODAP treatment.

- Administration of ODAP to white leghorn chicks and observation for signs of neurolathyrism: White leghorn chick brain proteome was analyzed following treatment with D-ODAP and L-ODAP for 2 and $4 \mathrm{hr}$. Previous experiments have shown that adult animals are resistant to ODAP and young animals are more prone to neurological deficits (35); hence, four-day-old white leghorn chicks were used for our study. In view of the fact that orally ingested ODAP is not metabolized in experimental animals (36) and chicks develop signs of paraplegia upon intraperitoneal administration of ODAP (37), we chose to administer ODAP by intraperitoneal route for our studies. A dose of $0.5 \mathrm{mg} / \mathrm{g}$ body weight of chicks was chosen based on previous studies conducted in our laboratory (26). Chicks were divided into three groups $(n=6$ per 


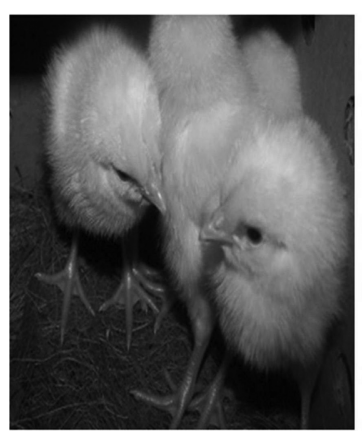

CONTROL

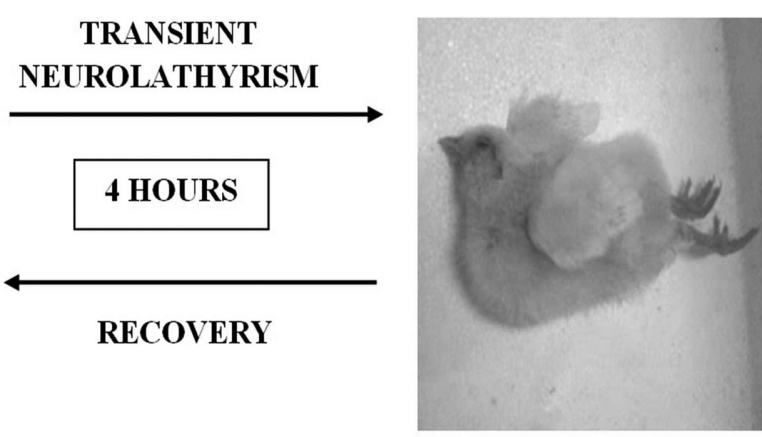

L- $\beta$-ODAP

Fig. 1. Transient neurolathyrism in chicks following ODAP administration. Four day old young white male leghorn chicks following intraperitoneal administration of L- $\beta$-ODAP showed characteristics such as inability to stand and walk, head retraction and drooping of wings. These symptoms decreased and became transient with the chicks trying to recover in $4 \mathrm{hr}$.

group). Two groups were injected with ODAP, wherein one group received D-ODAP and the other group received L-ODAP. Untreated chicks were included as a control group. Following administration of L-ODAP, symptoms of neurolathyrism, such as dropping of the head and inability to stand, started at $45 \mathrm{~min}$; the symptoms progressed to violent shaking from $2 \mathrm{hr}$ and continued till $3 \mathrm{hr}$. After $3 \mathrm{hr}$, there was a decline in the symptoms and chicks slowly started showing signs of recovery by $4 \mathrm{hr}$ (Fig. 1).

Table 1. Chick brain proteins differentially expressed under D- and L-ODAP treatments

\begin{tabular}{|c|c|c|c|c|c|c|c|c|c|}
\hline \multirow[b]{2}{*}{$\begin{array}{l}\text { Spot } \\
\text { no. }\end{array}$} & \multirow[b]{2}{*}{ Protein name } & \multirow[b]{2}{*}{$\begin{array}{l}\text { Accession } \\
\text { number }\end{array}$} & \multirow[b]{2}{*}{$\begin{array}{l}\mathrm{MW} \\
(\mathrm{Da}) / \mathrm{pI}\end{array}$} & \multirow[b]{2}{*}{$\begin{array}{l}\text { Mascot } \\
\text { score }\end{array}$} & \multirow[b]{2}{*}{$\begin{array}{l}\text { MOWSE } \\
\text { score }\end{array}$} & \multirow{2}{*}{$\begin{array}{l}\# \text { of } \\
\text { peptides } \\
\text { matched } \\
\text { (\%Seq. } \\
\text { coverage) }\end{array}$} & \multirow[b]{2}{*}{ Function } & \multicolumn{2}{|c|}{ Fold change ( $2 \mathrm{hr} ; 4 \mathrm{hr})$} \\
\hline & & & & & & & & D-ODAP & L-ODAP \\
\hline 1 & $\begin{array}{l}\text { Collapsin } \\
\text { response mediator } \\
\text { protein-2B }\end{array}$ & 33340025 & $62619 / 6.05$ & 114 & 7.9E-06 & $11(26)$ & Hydrolase activity & $0.85 ; 0.40$ & $0.19 ;-0.72$ \\
\hline 2 & $\begin{array}{l}\text { Apolipoprotein } \\
\text { AI }\end{array}$ & 227016 & $28790 / 5.45$ & 197 & $4.0 \mathrm{E}-14$ & $17(50)$ & $\begin{array}{l}\text { Cholesterol } \\
\text { metabolism }\end{array}$ & $1.80 ; 1.15$ & $0.66 ; 0.66$ \\
\hline 3 & Peroxiredoxin-1 & 429836849 & $22529 / 8.24$ & 101 & $1.6 \mathrm{E}-04$ & $7(31)$ & $\begin{array}{l}\text { Antioxidant } \\
\text { (Oxidoreductase) }\end{array}$ & $0.70 ; 1.42$ & ----; 0.77 \\
\hline 4 & $\begin{array}{l}\text { Carbonyl reductase } \\
\text { [NADPH] } 1\end{array}$ & 71895267 & $30520 / 8.50$ & 85 & 6.7E-03 & $6(23)$ & Oxidoreductase & $1.36 ; 1.39$ & $----; 0.73$ \\
\hline 5 & Dynactin subunit 2 & 45382201 & $45212 / 4.90$ & 87 & 4.1E-03 & $8(23)$ & Cytoskeletal protein & $1.99 ; 0.28$ & $----; 0.64$ \\
\hline 6 & Calretinin & 45384332 & $31171 / 5.10$ & 88 & $2.8 \mathrm{E}-03$ & $7(26)$ & $\begin{array}{l}\text { Calcium-binding } \\
\text { and signaling }\end{array}$ & $-0.31 ; 0.35$ & $1.94 ;-0.15$ \\
\hline 7 & $\begin{array}{l}\text { Phosphatidyl- } \\
\text { ethanolamine- } \\
\text { binding protein } 1\end{array}$ & 310772215 & $21115 / 6.96$ & 152 & $1.3 \mathrm{E}-09$ & $10(78)$ & EGFR1 signaling & $-0.26 ; 0.62$ & $1.52 ; 0.11$ \\
\hline 8 & $\begin{array}{l}\text { Phosphoglycerate } \\
\text { mutase } 1\end{array}$ & 71895985 & $29051 / 7.03$ & 92 & $1.1 \mathrm{E}-03$ & $8(42)$ & $\begin{array}{l}\text { Hydrolase, } \\
\text { Isomerase activity }\end{array}$ & $0.48 ;-0.25$ & $2.00 ;-0.69$ \\
\hline 9 & $\begin{array}{l}\text { Elongation factor } \\
\text { 1-beta }\end{array}$ & 53136666 & $25104 / 4.63$ & 100 & $2.1 \mathrm{E}-04$ & $8(30)$ & Nucleic acid binding & $2.10 ; 1.19$ & $3.21 ; 1.37$ \\
\hline 10 & Glutamine synthetase & 45382781 & $42747 / 6.38$ & 93 & $9.3 \mathrm{E}-04$ & $7(19)$ & $\begin{array}{l}\text { Nucleotide-binding } \\
\text { (Ligase, Lyase } \\
\text { activity) }\end{array}$ & $0.90 ; 1.48$ & $3.01 ;-0.93$ \\
\hline 11 & Tubulin beta- 2 chain & 52138699 & $50377 / 4.78$ & 193 & $9.9 \mathrm{E}-14$ & $20(32)$ & Cytoskeletal protein & $0.37 ; 4.20$ & $9.94 ; 1.56$ \\
\hline
\end{tabular}


Table 1. Continued

\begin{tabular}{|c|c|c|c|c|c|c|c|c|c|}
\hline \multirow[b]{2}{*}{$\begin{array}{l}\text { Spot } \\
\text { no. }\end{array}$} & \multirow[b]{2}{*}{ Protein name } & \multirow[b]{2}{*}{$\begin{array}{l}\text { Accession } \\
\text { number }\end{array}$} & \multirow[b]{2}{*}{$\begin{array}{l}\text { MW } \\
(\mathrm{Da}) / \mathrm{pI}\end{array}$} & \multirow[b]{2}{*}{$\begin{array}{l}\text { Mascot } \\
\text { score }\end{array}$} & \multirow[b]{2}{*}{$\begin{array}{l}\text { MOWSE } \\
\text { score }\end{array}$} & \multirow{2}{*}{$\begin{array}{l}\# \text { of } \\
\text { peptides } \\
\text { matched } \\
\text { (\%Seq. } \\
\text { coverage) }\end{array}$} & \multirow[b]{2}{*}{ Function } & \multicolumn{2}{|c|}{ Fold change ( $2 \mathrm{hr} ; 4 \mathrm{hr}$ ) } \\
\hline & & & & & & & & D-ODAP & L-ODAP \\
\hline 12 & $\begin{array}{l}\text { Chain A, crystal } \\
\text { structure of chicken } \\
\text { brain-type creatine } \\
\text { kinase at } 1.41 \\
\text { angstrom resolution }\end{array}$ & 6573489 & $42713 / 5.93$ & 115 & $6.3 \mathrm{E}-06$ & $9(28)$ & $\begin{array}{l}\text { Kinase and } \\
\text { Transferase activity }\end{array}$ & $0.19 ;----$ & $1.85 ;-0.66$ \\
\hline 13 & $\begin{array}{l}\text { Tropomyosin } \\
\text { alpha-3 chain }\end{array}$ & 350537089 & $28801 / 4.69$ & 176 & $5.0 \mathrm{E}-12$ & $14(38)$ & $\begin{array}{l}\text { Muscle protein } \\
\text { (Actin binding) }\end{array}$ & $1.49 ;-0.37$ & $2.16 ;-0.03$ \\
\hline 14 & $\begin{array}{l}\text { Heat shock cognate } \\
71 \mathrm{kDa} \text { protein }\end{array}$ & $\begin{array}{l}\text { Swiss Prot: } \\
\text { HSP7C_- } \\
\text { CHICK }\end{array}$ & $70783 / 5.47$ & 123 & 4.2E-08 & $13(25)$ & Chaperone & $-0.56 ; 0.80$ & $4.56 ; 0.30$ \\
\hline 15 & $\begin{array}{l}\text { V-type proton } \\
\text { ATPase subunit E } 1\end{array}$ & 57525423 & $26102 / 7.74$ & 80 & $2.1 \mathrm{E}-02$ & $6(19)$ & $\begin{array}{l}\text { Hydrogen ion } \\
\text { transport }\end{array}$ & $1.53 ; 0.97$ & $1.33 ;-0.27$ \\
\hline 16 & Alpha-enolase & 46048768 & $47275 / 6.17$ & 96 & 4.6E-04 & $8(27)$ & $\begin{array}{l}\text { Glycolysis } \\
\text { (Lyase activity) }\end{array}$ & $0.17 ; 1.10$ & $1.51 ;-0.10$ \\
\hline 17 & Cofilin-2 & 52138701 & $18765 / 7.66$ & 95 & $5.8 \mathrm{E}-04$ & $5(36)$ & Cytoskeletal protein & $1.35 ; 0.88$ & $1.22 ; 0.86$ \\
\hline 18 & $\begin{array}{l}\text { Fatty acid-binding } \\
\text { protein, brain }\end{array}$ & 45384320 & $15031 / 5.61$ & 129 & $2.5 \mathrm{E}-07$ & $7(71)$ & Lipid binding & $0.71 ;-0.001$ & $1.73 ;-0.39$ \\
\hline 19 & $\begin{array}{l}\text { Superoxide dismutase } \\
\text { [Cu-Zn] }\end{array}$ & 45384218 & $15979 / 6.10$ & 93 & $9.3 \mathrm{E}-04$ & $6(40)$ & $\begin{array}{l}\text { Antioxidant } \\
\text { (Oxidoreductase) }\end{array}$ & $-0.52 ;-0.25$ & $2.09 ; 0.12$ \\
\hline 20 & Ovotransferrin & 1351295 & $79551 / 6.85$ & 153 & $9.9 \mathrm{E}-10$ & $14(20)$ & $\begin{array}{l}\text { Iron-binding } \\
\text { transport protein }\end{array}$ & $0.33 ; 1.22$ & $1.19 ;-0.34$ \\
\hline 21 & $\begin{array}{l}\text { Transitional } \\
\text { endoplasmic } \\
\text { reticulum ATPase }\end{array}$ & 113206112 & $89953 / 5.14$ & 123 & $9.9 \mathrm{E}-07$ & $18(17)$ & Golgi organization & $0.54 ; 1.02$ & $1.15 ; 2.34$ \\
\hline 22 & $\begin{array}{l}\text { Fructose- } \\
\text { bisphosphate } \\
\text { aldolase C } \\
\end{array}$ & 330417943 & $39735 / 6.20$ & 130 & $2.0 \mathrm{E}-07$ & $15(39)$ & $\begin{array}{l}\text { Glycolysis } \\
\text { (Lyase activity) }\end{array}$ & $-0.06 ;-0.54$ & $2.19 ;-0.64$ \\
\hline 23 & $\begin{array}{l}\text { Ubiquitin carboxyl- } \\
\text { terminal hydrolase } \\
\text { isozyme L3 }\end{array}$ & 45382251 & $26469 / 4.91$ & 90 & $1.8 \mathrm{E}-03$ & $8(28)$ & $\begin{array}{l}\text { Hydrolase and } \\
\text { Protease activity }\end{array}$ & $1.49 ; 0.57$ & $-1.18 ; 0.17$ \\
\hline 24 & $\begin{array}{l}60 \mathrm{kDa} \text { heat } \\
\text { shock protein, } \\
\text { mitochondrial } \\
\text { precursor }\end{array}$ & 61098372 & $61105 / 5.72$ & 116 & $5.0 \mathrm{E}-06$ & $10(19)$ & Chaperone & $0.85 ; 0.48$ & $1.51 ; 1.34$ \\
\hline 25 & $\begin{array}{l}\text { Dihydropyrimidinase- } \\
\text { related protein } 2\end{array}$ & $\begin{array}{l}\text { Swiss Prot: } \\
\text { DPYL2- } \\
\text { CHICK }\end{array}$ & $62691 / 5.96$ & 68 & $1.4 \mathrm{E}-02$ & $6(11)$ & Neurogenesis & $0.24 ;-0.15$ & $----; 0.17$ \\
\hline 26 & Pyridoxal kinase & 363728772 & $35164 / 5.93$ & 83 & $1.1 \mathrm{E}-02$ & $5(18)$ & $\begin{array}{l}\text { Kinase and } \\
\text { Transferase activity }\end{array}$ & ----; ---- & $----; 1.72$ \\
\hline 27 & Tropomodulin-2 & 50752941 & $39439 / 5.71$ & 83 & $9.3 \mathrm{E}-03$ & $8(24)$ & Cytoskeletal protein & $0.62 ;-0.06$ & $----; 1.21$ \\
\hline 28 & Septin-5, partial & 449279189 & $46162 / 6.31$ & 95 & $6.4 \mathrm{E}-04$ & $8(22)$ & Nucleotide-binding & $1.44 ;-0.37$ & $----;-0.14$ \\
\hline 29 & $\begin{array}{l}\text { Prostaglandin-H2 } \\
\text { D-isomerase } \\
\text { precursor }\end{array}$ & 45383612 & $21001 / 6.30$ & 115 & $6.3 \mathrm{E}-06$ & $9(41)$ & Lipid metabolism & $-0.41 ;-0.23$ & $1.76 ; 0.62$ \\
\hline 30 & Protein DJ-1 & 45383015 & $20159 / 6.32$ & 115 & $6.3 \mathrm{E}-06$ & $11(40)$ & Chaperone & $0.01 ;-0.39$ & $1.49 ; 1.04$ \\
\hline
\end{tabular}


- Chick brain proteome profiling following ODAP treatments: Following ODAP administrations the chicks were observed for any signs of neurolathyrism and their brains were harvested at 2 and $4 \mathrm{hr}$ to study the varied brain protein profiles. 2D gels of chick brain homogenates without any treatment were used as control for the gel analysis. Analysis of gel images resulted in the detection of more than 200 spots per gel. Protein spots indicating significantly different expression were excised from gels and identified using MALDI-TOF/TOF analysis. Proteins identified with MASCOT MOWSE greater than 60 were taken as positive hits (Table 1). Fig. 2A represents the position of protein spots on the gels identified by MALDI-TOF/TOF analysis. Bioinformatics analysis of identified differentially expressed proteins revealed that they belong to different cellular locations, such as the cell membrane, cytoplasm, nucleus, and endoplasmic reticulum (Fig. 2B). The functional classification involving biological processes of the identified proteins based on their gene ontology was analyzed using the Protein Center soft- ware. Proteins identified were found to be involved in cellular metabolism, transport, response to stimulus, and cellular organization and development (Fig. 2C).

Differentially regulated proteins identified by MALDI$\mathrm{TOF} / \mathrm{TOF}$ were also queried in the STRING database (version 10.0) (38) to identify possible protein-protein interactions. Fig. 2D reveals the protein-protein interaction network represented by (a) nodes and (b) edges, where nodes depict the genes and edges depict the mapped interaction of the proteins encoded by the genes. The 30 proteins were queried in STRING with a medium confidence parameter of 0.5 under Gallus gallus taxonomy and the corresponding interaction information was retrieved by different prediction methods, such as text mining, experiments, databases, co-expression, and co-occurrence. The STRING database predicted interaction among 10 proteins; strong interactions represented by the increased number of interconnecting lines as seen in Fig. 2D, were among the antioxidants, chaperones, glycolytic enzymes, and proteins involved in cellular structure.
(A)

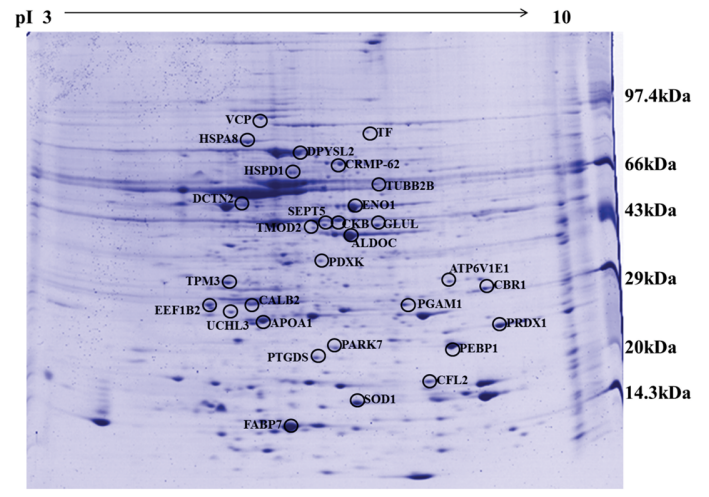

(C)

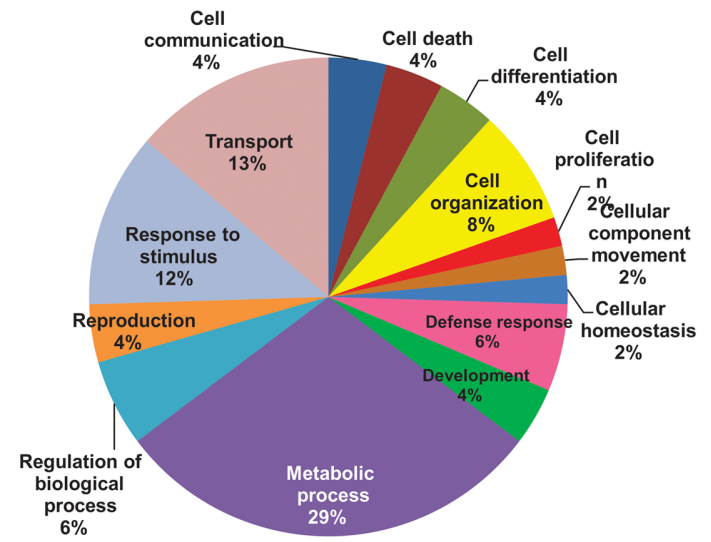

(B)

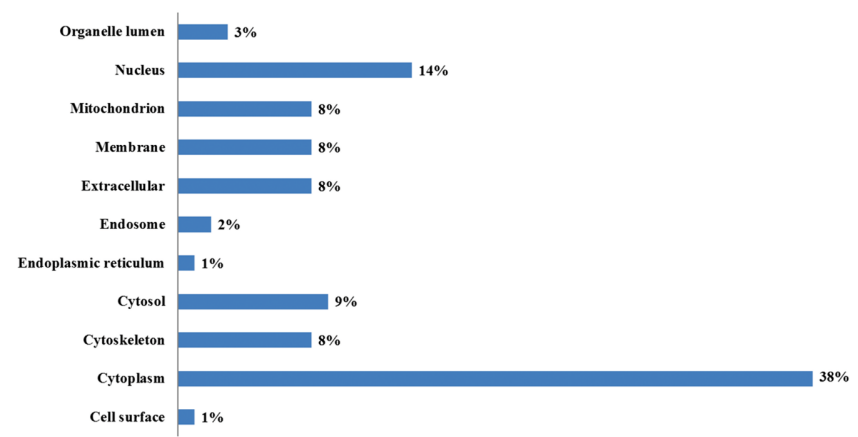

(D)

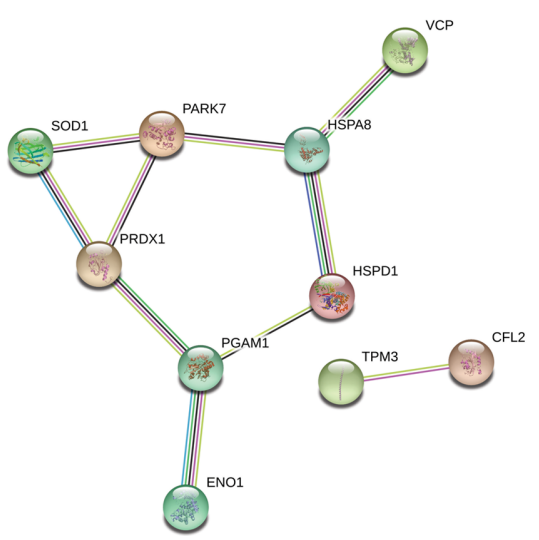

Fig. 2. Chick brain proteome analysis post $2 \mathrm{hr}$ and $4 \mathrm{hr}$ ODAP treatment. (A) Representative 2-D gel image of chick brain proteome depicting positions of 30 differentially expressed spots identified by MALDI TOF/TOF, (B) Gene Ontology cellular component analysis and (C) Gene Ontology molecular function analysis of identified proteins. (D) Protein-protein interaction networks obtained on the basis of confidence and evidence. More number of interconnecting lines between two proteins is implicative of stronger evidence for the protein-protein interaction. 
- Chick brain proteins regulated by ODAP: Many of the identified proteins significantly affected by treatments were those involved in cytoskeletal structure formation, free radical scavenging, synaptic transmission, signal transduction, calcium ion regulation, neuronal degeneration, transport, metabolic pathways, oxidative stress, and protein folding and degradation. Cytoskeletal proteins (tubulin, cofilin-2, and tropomyosin), glycolytic enzymes (phosphoglyceratemutase, alpha-enolase, fructose-bisphosphatealdolase), and proteins playing a role in signaling (PEBP1 and calretinin) and free radical scavenging (SOD), were all initially up-regulated at $2 \mathrm{hr}$; however, their levels returned to normal by $4 \mathrm{hr}$ following L-ODAP administration. Oxidative stress is known to play an important role in neurodegenerative disorders such as Alzheimer's disease, Parkinson's disease, and other forms of dementia. Proteins such as heat shock cognate $(71 \mathrm{kDa})$, alpha-enolase, and DJ-1, implicated in oxidative stress-related neurodegenerative disorders such as Alzheimer's disease (39) and
Parkinson's disease (40) showed a similar up-regulation at $2 \mathrm{hr}$ followed by a drop to normal levels by $4 \mathrm{hr}$. L-ODAP is mainly known to cause neuronal dysfunction by the excessive activation of glutamate receptors, a process called excitotoxicity $(16,41)$. The expression of glutamine synthetase, responsible for the conversion of glutamate to glutamine, was initially up-regulated at $2 \mathrm{hr}$ but returned to normal levels by $4 \mathrm{hr}$ under L-ODAP treatment in the chick brain (Table 1).

\section{In vitro studies to assess L-ODAP-mediated oxida- tive stress and apoptosis. \\ - Mitochondrial membrane potential alteration:} Since L-ODAP is known to cause redox imbalance leading to mitochondrial dysfunction (24), mitochondrial membrane potential was evaluated. Based on a previous study on brain cells (42), a 10-fold lower sub-lethal concentration of $200 \mu \mathrm{M}$ ODAP was chosen for in vitro studies. The human neuroblastoma cell line IMR-32 was treated
(A)

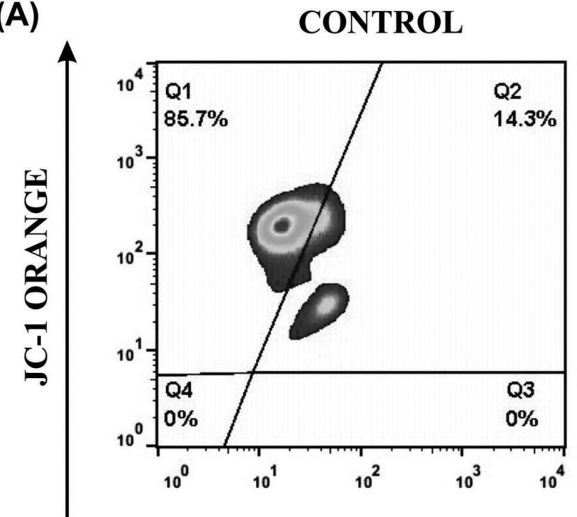

D-ODAP

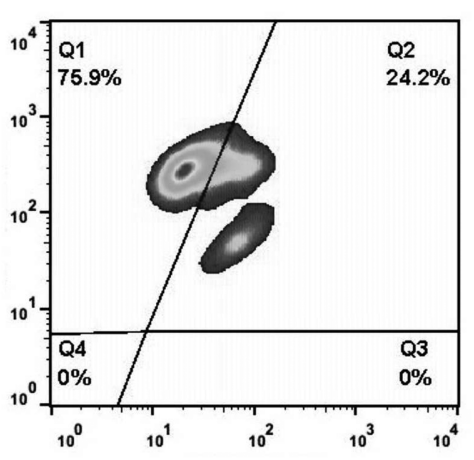

L-ODAP

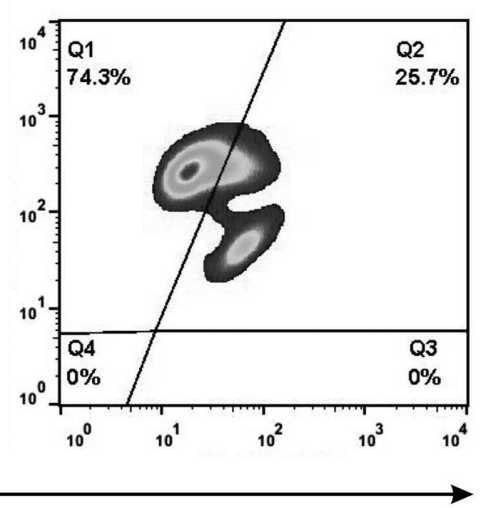

JC-1 GREEN

(B)

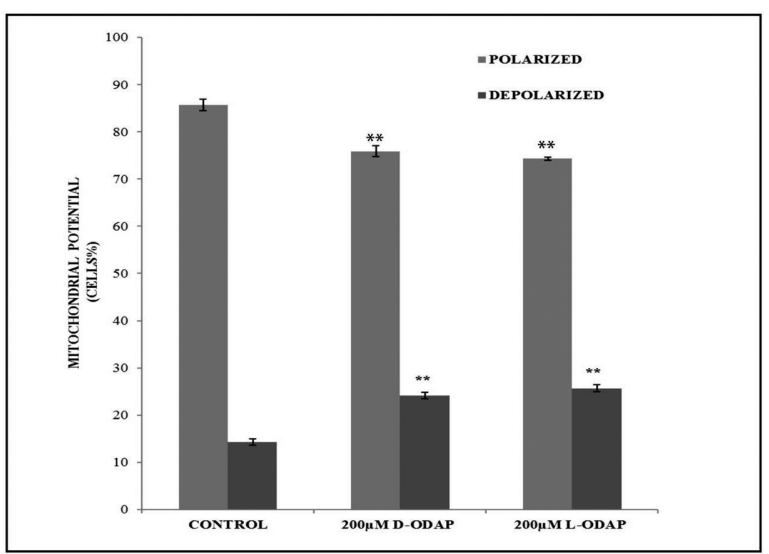

Fig. 3. Effect of ODAP on mitochondrial membrane potential. Cells treated with $200 \mu \mathrm{M}$ D- and L-ODAP for $4 \mathrm{hr}$, were stained with JC-1 dye which fluoresces green or orange depending on mitochondrial membrane depolarization. (A) Representative image showing the percentage of cells with polarized and depolarized mitochondrial membrane. (B) Bar graph data represents average of percentage of cells showing depolarized mitochondria/polarized mitochondria \pm standard error of mean (SEM) calculated from three independent experiments $(n=3) .{ }^{* *}$ Indicate values significantly different from untreated control $(p<0.005)$. 
with D- and L-ODAP for $4 \mathrm{hr}$ and mitochondrial membrane potential was assessed. As seen from Fig. 3, the percentage of depolarized cells after D-ODAP and L-ODAP treatments was observed to be $24.2 \pm 0.66 \%$ and $27.5 \pm$ $0.72 \%$, respectively, indicating an increase of 1.7 -fold and 1.8-fold, respectively, compared to control.

- Intracellular ROS production in the presence of ODAP: Intracellular generation of ROS is an indication for apoptosis induction in various cell types. L-ODAP is known to cause oxidative stress and redox imbalance. The proteome analysis of chick brain homogenates revealed differential regulation of ROS scavengers during L-ODAP treatment. A 1.8-fold increase in the percentage of depolarized cells after L-ODAP treatment prompted us to measure the ROS levels in IMR-32 cells following treatment with $200 \mu \mathrm{M}$ ODAP for $4 \mathrm{hr}$. The ROS levels were assessed using the oxygen-sensitive dye DCFH-DA by flow cytometry. Cell-permeable DCFH-DA is cleaved intracellularly by esterases to DCFH, which is further oxidized by the ROS produced within the cells to the fluorescent form, DCF, the fluorescence intensity being directly proportional to the ROS generated. As seen from Fig. 4, the mean fluorescent intensities (MFIs) indicative of ROS levels were $19.1 \pm 0.4,24.3 \pm 0.2$, and $24.4 \pm 0.2$ in untreated control, $200 \mu \mathrm{M}$ D-ODAP treatment, and 200 $\mu \mathrm{M}$ L-ODAP treatment groups, respectively. An MFI of $59.2 \pm 1.2$ was observed for the positive control $100 \mu \mathrm{M}$ hydrogen peroxide treatment group. Thus, the ROS levels increased by three-fold after $\mathrm{H}_{2} \mathrm{O}_{2}$ treatment and by 1.2fold following D- and L-ODAP treatments compared to control.

- Apoptosis induction and caspase activation: Apoptosis assays were carried out in IMR-32 cells following ODAP treatment to evaluate if it triggered any apoptosis at $200 \mu \mathrm{M}$ concentration. Early apoptosis was assessed by quantifying phosphatidylserine through annexin VFITC conjugate, which has a strong affinity to phosphatidylserine. As seen from Fig. 5, $6.8 \pm 0.57 \%$ and $7.7 \pm$ $0.43 \%$ early apoptotic cells were observed following treatment with $200 \mu \mathrm{M}$ D-ODAP and L-ODAP, respectively, which are not significant in terms of initiation of apoptosis as compared to untreated control showing $5.3 \pm 0.63 \%$
(A)

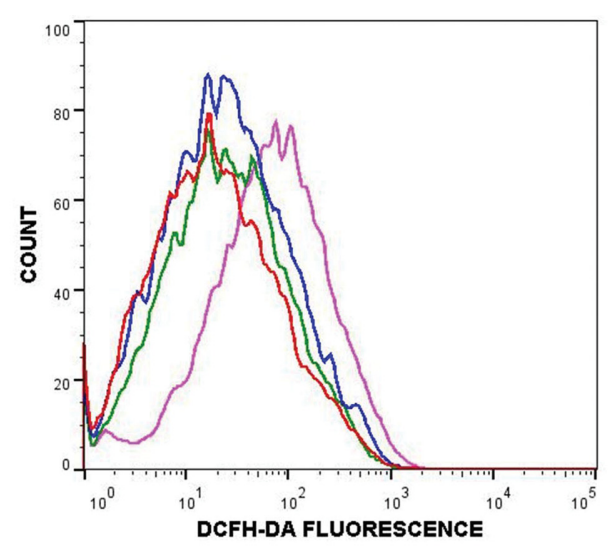

\begin{tabular}{|c|c|}
\hline Sample Name & Geometric Mean : GRN-HLog \\
\hline IMR CONTROL.FCS & 19.1 \\
\hline 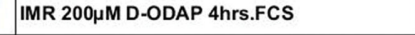 & 24.3 \\
\hline 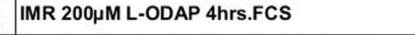 & 24.4 \\
\hline 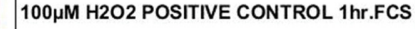 & 59.2 \\
\hline
\end{tabular}

(B)

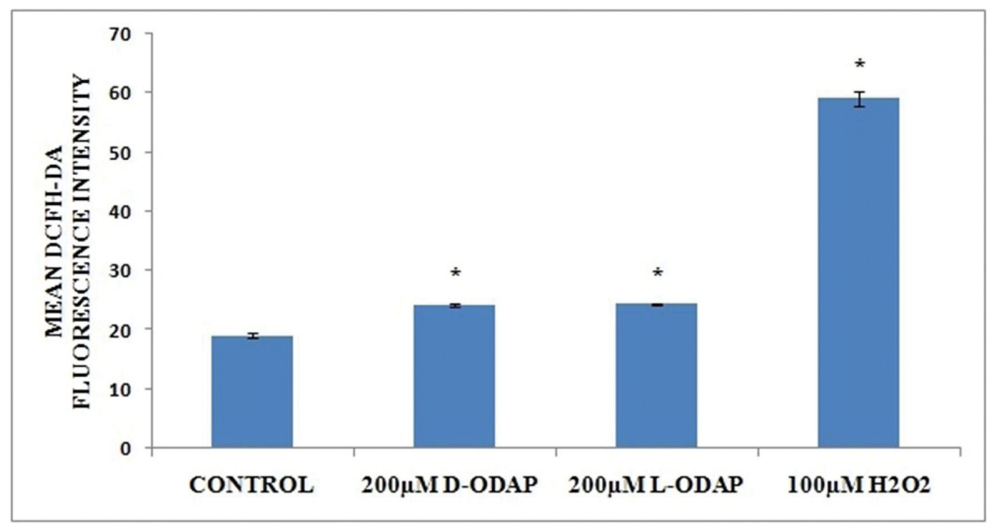

Fig. 4. Effect of ODAP on ROS production. ROS production was evaluated by DCFH-DA assay and analysed by flow cytometry. (A) Representative flow cytometric histograms and (B) representative graph depicting mean fluorescent intensities proportional to ROS production under treatment with $200 \mu \mathrm{M}$ ODAP for $4 \mathrm{hr}$. Untreated IMR-32 cells were used as control, whereas those treated with hydrogen peroxide served as positive control. Data and error bars represent the average and standard error of mean of three independent experiments $(n=3) .{ }^{*}$ Indicate values significantly different from untreated control $(p<0.05)$. 
(A)

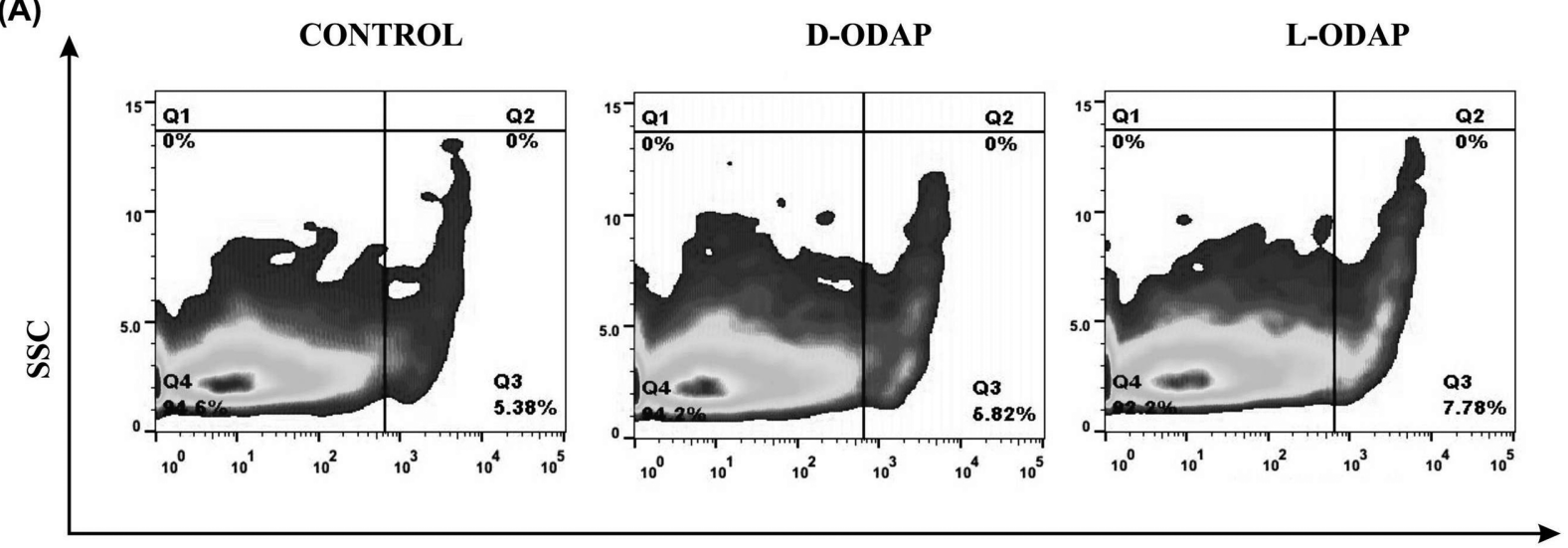

ANNEXIN V - FITC

(B)

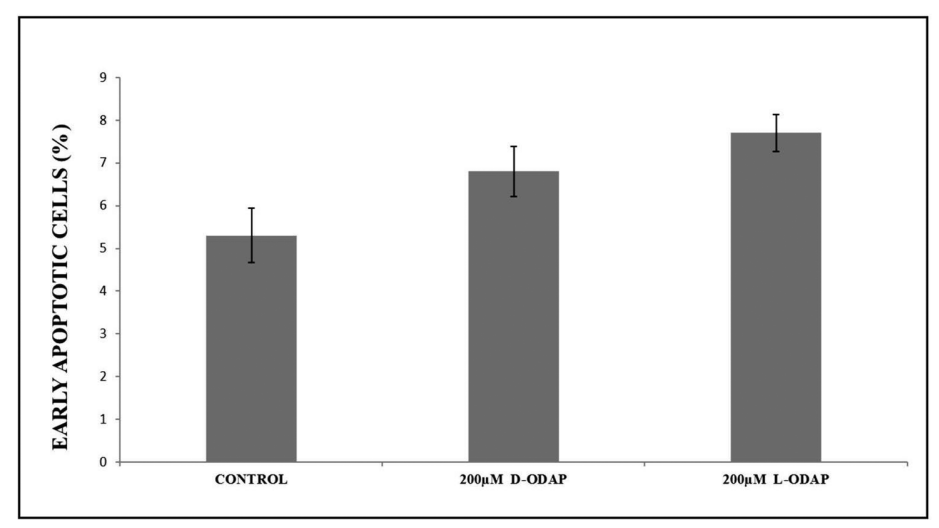

Fig. 5. Effect of ODAP on early apoptosis. (A) Graph representing percentage of annexin V positive IMR cells following treatment with $200 \mu \mathrm{M}$ D- and L-ODAP for $4 \mathrm{hr}$. (B) Bar graph depicts percentage of annexin V positive cell population. Data represents average and standard error of mean from three independent experiments $(n=3)$.

early apoptotic cells. The effect of L-ODAP on the active caspases, the main executioners of apoptosis, was also assayed in IMR-32 cells. The cells were treated with $200 \mu \mathrm{M}$ D- and L-ODAP for $4 \mathrm{hr}$ and active caspase levels were checked by flow cytometry through FAM-labeled active caspase inhibitors. MFI values indicative of active caspases were $26.9 \pm 0.57$ and $24.3 \pm 0.58$ when treated with D- and L-ODAP, respectively, which are similar to that of untreated control (24.6 \pm 0.7$)$ (Fig. 6). The level of active caspases following L-ODAP treatment was 0.3 units (MFI value) more than that for untreated control.

\section{DISCUSSION}

The present study is the first attempt to analyze the brain proteome of young chicks injected with L-ODAP, as well as to identify proteins differentially modulated by this neurotoxin. There are remarkable species differences in susceptibility to L-ODAP; chicks are readily susceptible to transient intoxication by L-ODAP, whereas adult rats or mice do not develop neurodegenerative changes (43), though behavioral changes reminiscent of an excitable status can be reproducibly detected (44). Hence, young fourday-old chicks were chosen as an experimental model for the brain proteome-based transient neurolathyrism study. Following intraperitoneal L-ODAP administration, chicks showed pathological signs of lathyrism within $45 \mathrm{~min}$, acute-phase symptoms, such as the inability to stand and walk, head retraction, and drooping of wings, were more profound in the L-ODAP group than in the D-ODAP group. However, corroborating with previous studies carried out on chicks (45), these manifestations decreased and became transient as the chicks tended to recover in about $4 \mathrm{hr}$.

Proteome analysis of chick brain homogenates revealed that L-ODAP momentarily modulates the proteins involved in the formation of the cytoskeletal structure (tubulin, cofilin-2, and tropomyosin) and signaling (PEBP1 and calretinin). L-ODAP generates free radicals (24), observed by an initial up-regulation of the free radical scavenger SOD at $2 \mathrm{hr}$. However, the levels of SOD returned to normal at $4 \mathrm{hr}$ indicative of the transient effect of L-ODAP. A similar pattern was also observed for oxidative stress-related 
(A)

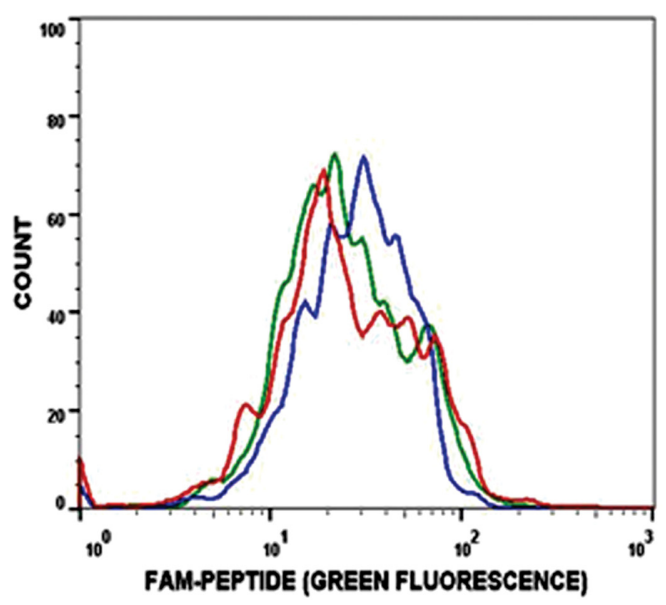

\begin{tabular}{|l|l|r|}
\hline & \multicolumn{1}{|c|}{ Sample Name } & Geometric Mean : GRN-HLog \\
\hline & IMR CONTROL.FCS & 24.6 \\
\hline & IMR 200MM D.ODAP 4hrs.FCS & 26.9 \\
\hline & IMR 200MM L-ODAP 4hrs.FCS & 24.3 \\
\hline
\end{tabular}

(B)

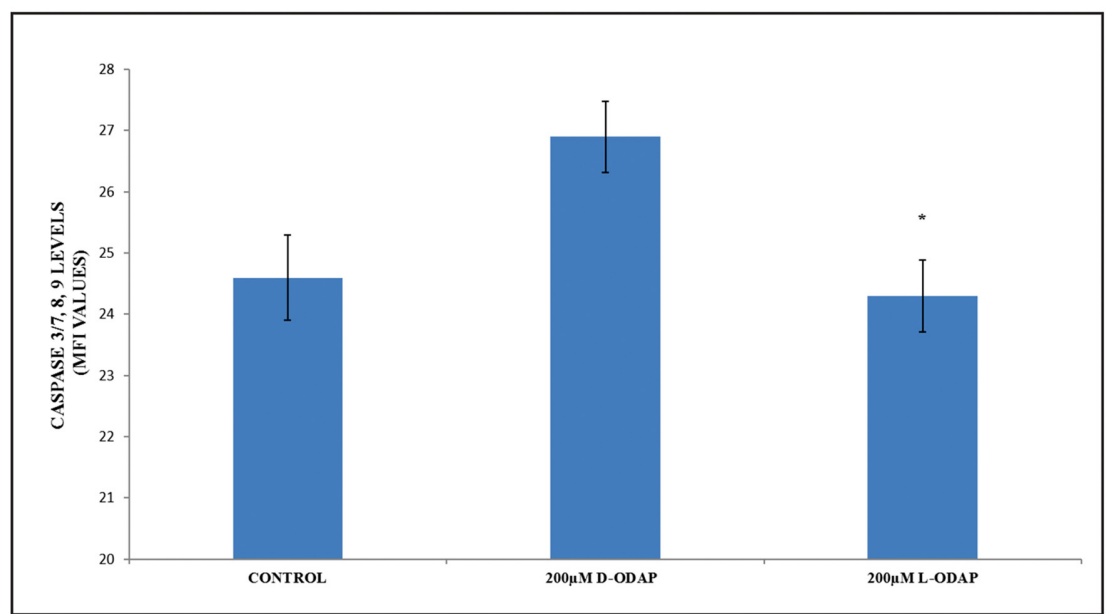

Fig. 6. Effect of ODAP on levels of active caspases. (A) Representative histogram showing caspase activity in IMR cells following treatment with $200 \mu \mathrm{M}$ D- and L-ODAP for $4 \mathrm{hr}$. Cells were incubated with FAM-labeled caspase inhibitor and caspase activation was analysed by flow cytometer. The table on the right represents MFI values of the active caspases, namely, caspase 3/7, 8 and 9 . (B) Bar graph representing caspase activity (expressed as MFI values). Data and error bars represent the average and standard error of mean of three independent experiments $(n=3) .{ }^{*}$ Indicate values significantly different from untreated control $(p<0.05)$.

proteins implicated in Alzheimer's and Parkinson's diseases, indicating that the oxidative stress-induced neurolathyrism caused by L-ODAP is temporary. Adding to the present findings of transient lathyrism observed in chicks, the levels of glutamine synthase returned to normal by $4 \mathrm{hr}$, indicative of a short-lived excitotoxicity.

Excitotoxicity resulting in disturbances in calcium homeostasis and leading to oxidative stress has been implicated in the etiology of various neurodegenerative disorders such as Alzheimer's disease, Parkinson's disease, and neurolathyrism (30). Oxidative stress can alter the mitochondrial membrane permeability, stimulating ROS production and the release of proapoptotic factors such as cytochrome $\mathrm{c}$ into the cytoplasm leading to cell death (46). In neurolathyrism, L-ODAP has been shown to increase ROS production and inhibit the activity of antioxidant enzymes (16). Interestingly, the present proteomic study carried out on chick brain extracts found that the effects of L-ODAP were transient and proteins involved in cellular metabolism pathways, signaling, and neurodegeneration recovered to normal levels by $4 \mathrm{hr}$ after ODAP treatments, suggestive of a recuperative strategy toward ODAP-mediated toxicity.

The ability of $200 \mu \mathrm{M}$ L-ODAP to increase ROS production, thereby inflicting mitochondrial damage and finally leading to apoptosis, was further evaluated using the human neuroblastoma cell line IMR-32. Although the biologically active isomer L-ODAP increased intracellular ROS and the percentage of cells with a depolarized mitochondrial membrane by 1.2- and 1.8-fold compared to untreated control, both $\mathrm{D}$ and $\mathrm{L}$ isomers of ODAP did not lead to the initiation of apoptosis or activation of caspases.

In conclusion, this is the first study on the proteomic 
analysis of ODAP-administered chick brain, highlighting the proteins responsible for transient lathyrism and its recovery. Apoptosis assays carried out on human neuroblastoma cells revealed that ODAP $(200 \mu \mathrm{M})$ does not lead to the initiation of apoptosis or activation of caspases after $4 \mathrm{hr}$. Low levels of ROS can act as second messengers and are also known to alter the function of the transcription factor HIF-1 (47). Since L-ODAP activates protein kinase C (26) and stabilizes HIF (48), which is known to mediate angiogenesis, invasion, and cell survival (49), this study further opens up avenues to explore the beneficial effects of this amino acid as an initiator of ROS- and HIF1-mediated signaling cascades.

\section{ACKNOWLEDGMENTS}

University Grants Commission, India is duly acknowledged for providing research fellowship (BSR) to Anil Kumar D and funding to the Department of Biochemistry, Osmania University in the form of SAP-DRS-III. Authors are thankful to the Department of Zoology, Osmania University for providing access to the animal house facility. Authors also thank the Department of Biotechnology (DBT)-OU-ISLARE, Osmania University for providing access to the instrumentation facility.

\section{CONFLICT OF INTEREST}

The authors declare that there are no conflicts of interest.

Received January 9, 2018; Revised May 31, 2018; Accepted June 12, 2018

\section{REFERENCES}

1. Haque, A., Hossain, M., Wouters, G. and Lambein, F. (1996) Epidemiological study of lathyrism in northwestern districts of Bangladesh. Neuroepidemiology, 15, 83-91.

2. Getahun, H., Mekonnen, A., Teklehaimanot, R. and Lambein, F. (1999) Epidemic of neurolathyrism in Ethiopia. Lancet, 354, 306-307.

3. De falco, E. and Pardo, A. (2000) Agronomic evaluation of Italian ecotypes of Lathyrus sativus L. in a hilly area of southern Italy. Lathyrus Lathyrism Newsl., 1, 27.

4. Kuo, Y.H., Bau, H.M., Rozan, P., Chowdhury, B. and Lambein, F. (2000) Reduction efficiency of the neurotoxin $\beta$ ODAP in low-toxin varieties of Lathyrus sativus seeds by solid state fermentation with Aspergillus oryzae and Rhizopus microsporus var chinensis. J. Sci. Food Agric., 80, 2209-2215.

5. Selye, H. (1957) Lathyrism. Rev. Can. Biol., 16, 1-2.

6. Ludolph, A.C., Hugon, J., Dwivedi, M.P., Schaumburg, H.H. and Spencer, P.S. (1987) Studies on the etiology and pathogenesis of motor neuron disease. 1 Lathyrism: clinical findings in established cases. Brain, 110, 149-165.

7. Spencer, P.S., Ludolph, A.C. and Kisby, G.E. (1993) Neuro- logic diseases associated with use of plant components with toxic potential. Environ. Res., 62, 106-113.

8. Getahun, H., Lambein, F. and Vanhoorne, M. (2002) Neurolathyrism in Ethiopia: assessment and comparison of knowledge and attitude of health workers and rural inhabitants. Soc. Sci. Med., 54,1513-1524.

9. Murti, V.V.S. and Seshadri, T.R. (1964) Toxic amino acids of plants. Curr. Sci. (India), 33, 323-329.

10. Rao, S.L.N., Adiga, P.R. and Sarma, P.S. (1964) The isolation and characterization of $\beta$-N-oxalyl-L- $\alpha, \beta$-diaminopropionic acid: a neurotoxin from the Seeds of Lathyrus sativus. Biochemistry, 3, 432-436.

11. Ross, S.M., Roy, D.N. and Spencer, P.S. (1985) $\beta$-N-Oxalylamino-L-alanine: action on high-affinity transport of neurotransmitters in rat brain and spinal cord synaptosomes. $J$. Neurochem., 44, 886-892.

12. Spencer, P.S., Roy, D.N., Ludolph, A.C., Hugon, J. and Schaumburg, H.H. (1986) Lathyrism: evidence for role of the neuroexcitatory amino acid BOOA. Lancet, 2, 10661067.

13. Nunn, P.B., Seelig, M., Zagoren, J.C. and Spencer, P.S. (1987) Stereospecific acute neuronotoxicity of 'uncommon' plant amino acids linked to human motor-system diseases. Brain. Res., 410, 375-379.

14. Kuo, Y.H., Ikegami, F. and Lambein, F. (1998) Metabolic routes of $\beta$-(isoxazolin-5-on-2-yl)-L-alanine (BIA), the precursor of the neurotoxin ODAP ( $\beta$-n-oxalyl-1- $\alpha, \beta$,-diaminopropionic acid), in different legume seedlings. Phytochemistry, 49, 43-48.

15. Getahun, H., Lambein, F., Vanhoorne, M. and Van Der Stuyft, P. (2005) Neurolathyrism risk depends on type of grass pea preparation and on mixing with cereals and antioxidants. Trop. Med. Int. Health, 10, 169-178.

16. Van Moorhem, M., Lambien, F. and Leybaert, L. (2011) Unraveling the mechanism of $\beta$-N-oxalyl- $\alpha, \beta$-diaminopropionic acid ( $\beta$-ODAP) induced excitotoxicity and oxidative stress, relevance for neurolathyrism prevention. Food Chem. Toxicol., 49, 550-555.

17. Wu, G., Bowlus, S.B., Kim, K.S. and Haskell, B.E. (1976) L-2-Oxalylamino-3-aminopropionic acid, an isomer of Lathyrus sativus neurotoxin. Phytochemistry, 15, 1257-1259.

18. Chase, R.A., Pearson, S., Nunn, P.B. and Lantos, P.L. (1985) Comparative toxicities of $\alpha$ - and $\beta$-N-oxalyl-L- $\alpha, \beta$-diaminopropionic acid to rat spinal cord. Neurosci. Lett., 55, 89-94.

19. Mehta, T., Zarghami, N.S., Parker, A.J., Cusick, P.K. and Haskell, B.E. (1979) Neurotoxicity of orally or intraperitoneally administered L-3-oxalylamino-2-aminopropionic acid in the mouse. Toxicol. Appl. Pharmacol., 48, 1-9.

20. Bridges, R.J., Stevens, D.R., Kahle, J.S., Nunn, P.B., Kadri, M. and Cotman, C.W. (1989) Structure-function studies on N-oxalyl-diamino-dicarboxylic acids and excitatory amino acid receptors: evidence that beta-L-ODAP is a selective non-NMDA agonist. J. Neurosci., 9, 2073-2079.

21. Ross, S.M., Roy, D.N. and Spencer, P.S. (1989) Beta-Noxalylamino-L-alanine action on glutamate receptors. $J$. Neurochem., 53, 710-715.

22. Zeevalk, G.D. and Nicklas, W. J. (1989) Acute excitotoxicity in chick retina caused by the unusual amino acids BOAA and BMAA: effects of MK-801 and kynurenate. Neurosci. 
Lett., 102, 284-290.

23. Van Moorhem, M., Decrock, E., Coussee, E., Faes, L., De Vuyst, E., Vranckx, K., De Bock, M., Wang, N., D’Herde, K., Lambein, F., Callewaert, G. and Leybaert, L. (2010) Lbeta-ODAP alters mitochondrial $\mathrm{Ca}^{2+}$ handling as an early event in excitotoxicity. Cell Calcium, 47, 287-296.

24. Sriram, K., Shankar, S.K., Boyd, M.R. and Ravindranath, V. (1998) Thiol oxidation and loss of mitochondrial complex I precede excitatory amino acid-mediated neurodegeneration. J. Neurosci., 18, 10287-10296.

25. Singh, M.R., Pratap Rudra, M., Rao, S.L.N. and Singh, S. (2004) In vitro activation of protein kinase C by beta-Noxalyl-L-alpha,beta-diaminopropionic acid, the Lathyrus sativus neurotoxin. Neurochem. Res., 29, 1343-1348.

26. Jammulamadaka, N., Burgula, S., Medisetty, R., Ilavazhagan, G., Rao, S.L.N. and Singh, S.S. (2011) $\beta$-N-oxalyl-L$\alpha, \beta$-diaminopropionic acid regulates mitogen-activated protein kinase signaling by down-regulation of phosphatidylethanolamine-binding protein 1. J. Neurochem., 118, 176-186.

27. Rao, S.L.N., Ramachandran, L.K. and Adiga, P.R. (1963) The isolation and characterization of L-homoarginine from the seeds of Lathyrus sativus. Biochemistry, 2, 298-300.

28. Huang, L.F., Shi, H.L., Gao, B., Wu, H., Yang, L., Wu, X.J. and Wang, Z.T. (2014) Dencichine enhances hemostasis of activated platelets via AMPA receptors. Thromb. Res., 133, 848-854.

29. Rao, S.L.N. (2011) A look at the brighter facets of $\beta-N-$ oxalyl-L- $\alpha, \beta$-diaminopropionic acid, homoarginine and the grass pea. Food Chem. Toxicol., 49, 620-622.

30. Khandare, A.L., Ankulu, M. and Aparna, N. (2013) Role of glutamate and nitric oxide in onset of motor neuron degeneration in neurolathyrism. Neurotoxicology, 34, 269-274.

31. Dixit, G.P., Parihar, A.K., Bohra, A. and Singh, N.P. (2016) Achievements and prospects of grass pea (Lathyrus sativus L.) improvement for sustainable food production. Crop J., 4, 407-416.

32. Anand, U. (2016) ICMR panel clears 'unsafe' khesari dal banned in 1961. The Indian Express. New Delhi.

33. Le Bel, C.P., Ali, S.F., McKee, M. and Bondy, S.C. (1990) Organometal-inducedincreases in oxygen reactive species: the potential of $2^{\prime}, 7^{\prime}$-dichlorofluorescein diacetate as an index of neurotoxic damage. Toxicol. Appl. Pharmacol., 104, 17-24.

34. Kim, H.B. and Yoo, B.S. (2016) Propolis inhibits UVAinduced apoptosis of human keratinocyte HaCaT cells by scavenging ROS. Toxicol. Res., 32, 345-351.

35. Roy, O.N. (1988) The neurotoxic disease lathyrism. Natl. Med. J. India, 1, 70-80.

36. Jyothi, P., Prataprudra, M. and Rao, S.L.N. (1998) In vivo metabolism of $\beta$-N-oxalyl-L- $\alpha, \beta$-diaminopropionic acid: the Lathyrus sativus neurotoxin in experimental animals. Nat.
Toxins., 6, 189-195.

37. Rao, S.L.N., Malathi, K. and Sarma, P.S. (1969) Lathyrism. World Rev. Nutr. Diet., 10, 214-238.

38. Von Mering, C., Jensen, L.J., Kuhn, M., Chaffron, S., Doerks, T., Krger, B., Snel, B. and Bork, P. (2007) STRING 7-recent developments in the integration and prediction of protein interactions. Nucleic. Acids. Res., 35, D358-D362.

39. Castegna, A., Aksenov, M., Thongboonkerd, V., Klein, J.B., Pierce, W.M., Booze, R., Markesbery, W.R. and Butterfield, D.A. (2002) Proteomic identification of oxidatively modified proteins in Alzheimer's disease brain. Part II. Dihydropyrimidinase-related protein 2, alpha-enolase and heat shock cognate 71. J. Neurochem., 82, 1524-1532.

40. Hwang, O. (2013) Role of oxidative stress in Parkinson's disease. Exp. Neurobiol., 22, 11-17.

41. Lambein, F., Kuo, Y.H., Kusama-Eguchi, K. and Ikegami, F. (2007) 3-N-oxalyl-L-2,3-diaminopropanoic acid, a multifunctional plant metabolite of toxic reputation. Arkivoc, 4552.

42. Bridges, R.J., Hatalski, C., Shim, S.N. and Nunn, P.B. (1991) Gliotoxic properties of the Lathyrus excitotoxin $\beta-\mathrm{N}$ oxalyl-L- $\alpha, \beta$-diaminopropionic acid ( $\beta$-L-ODAP). Brain Res., 561, 262-268.

43. Rao, S.L.N. (1978) Entry of beta-N-oxalyl-L-alpha,betadiaminopropionic acid, the Lathyrus sativus neurotoxin into the central nervous sysytem of the adult rat, chick and the rhesus monkey. J. Neurochem., 30, 1467-1470.

44. La Bella, V. and Piccoli, F. (2000) Differential effect of $\beta-N-$ oxalylamino-L-alanine, the Lathyrus sativus neurotoxin, and (+/-)- $\alpha$-amino-3-hydroxy-5-methylisoxazole-4-propionate on the excitatory amino acid and taurine levels in the brain of freely moving rats. Neurochem. Int., 36, 523-530.

45. Roy, D.N., Nagaraja, V. and Gopalan, C. (1963) Production of neurolathyrism in chicks by injection of Lathyrus sativus concentrates. Curr. Sci., 32, 116-118.

46. Dong, X.X., Wang, Y. and Qin, Z.H. (2009) Molecular mechanisms of excitotoxicity and their relevance to pathogenesis of neurodegenerative diseases. Acta. Pharmacol. Sin., 30, 379-387.

47. Qutub, A.A. and Popel, A.S. (2008) Reactive oxygen species regulate hypoxia-inducible factor 1 alpha differentially in cancer and ischemia. Mol. Cell. Biol., 28, 5106-5119.

48. Eslavath, R.K., Sharma, D., Bin Omar, N.A.M., Chikati, R., Teli, M.K., Rajanikant, G.K. and Singh, S.S. (2016) $\beta-N-$ oxalyl-L- $\alpha, \beta$-diaminopropionic acid induces HRE expression by inhibiting HIF-prolyl hydroxylase-2 in normoxic conditions. Eur. J. Pharmacol., 791, 405-411.

49. Park, H. (2008) Novel dioxygenases, HIF- $\alpha$ specific prolylhydroxylase and asparanginyl-hydroxylase: $\mathrm{O}_{2}$ switch for cell survival. Toxicol. Res., 24, 101-107. 